Ethiopian Journal of Environmental Studies \& Management 8(5): 471 - 483, 2015.

ISSN:1998-0507

doi: http://dx.doi.org/10.4314/ejesm.v8i5.1

Submitted: October 29, 2014

Accepted: June 02, 2015

\title{
URBAN LAND USE IN THE CITY CENTRE OF AKURE, NIGERIA
}

\author{
*ORIYE, 0.1 AND FAKERE, A.A. ${ }^{2}$ \\ ${ }^{1}$ Department of Architecture, College of Environmental Sciences, Joseph Ayo Babalola \\ University, Ikeji-Arakeji, Osun State, Nigeria \\ ${ }^{2}$ Department of Architecture, School of Environmental Technology, Federal University of \\ Technology, Akure, Ondo State, Nigeria
}

\begin{abstract}
Land is germane to virtually all developmental activities of man. The manner in which it is utilized goes a long way to determine the shape and form of cities. Land is used for several purposes ranging from recreational, commercial, residential, industrial and religious. The combination of these uses depends on their relationship. People tend to misuse land or put it to improper use, for example, it is improper to locate a mechanic workshop very close to a residential area. Town Planning and Urban Development Authorities are vested with the responsibility of controlling and maintaining physical development of the city. They make sure that land developers do not exceed the boundaries established by the Masterplan and building bye-laws. In the restoration of cities, illegal structures will be demolished and as the case may be, compensations will have to be made wherever necessary. This paper utilized controlled observations, interviews and structured questionnaires in the collection of data. It takes a look at the general Land Use patterns in Akure city centre. The city centre for this paper is defined by the area covered by Akure in the year 1966. It further suggested correctional measures that would restore the quality of the city centre where the planning regulations have not been adhered to.
\end{abstract}

Key Words: City Centre, Land Use, Pattern, Physical Development

\section{Introduction}

Land Use according to Encarta Dictionary (2009), refers to the way the solid part of the earth that is not covered by water is employed for a certain purpose. Pocket Oxford Dictionary (1994), as well, describes it as the manner in which the solid part of the earth's crust is caused to serve a purpose.Land use is characterized by the arrangements, activities and inputs people undertake in a certain land cover type to produce, change or maintain it, (FAO/UNEP, 1999). Man (Homo sapiens) makes use of the land he inhabits to a degree unmatched by any other species. The human imprint is most marked in the temperate and tropical zones, but even in remote deserts, high mountains, and polar region bear evidence of the works of Man.

In large urban and industrial centres and major transportation networks, the alteration of the landscape is most evident. Land occupied by farms, plantations, and pasture may seem more 'natural', but these forms of development are the products of human activity just as surely as densely populated cities, sprawling factory complexes, and bustling international

*Corresponding author: Oriye, $\mathrm{O}$.

Email: segunoriye@gmail.com 
airports. Human land use even extends to the oceans, where people appropriate the surface for maritime traffic lanes; comb the waters below for fish, squid, algae, and other items of value; and mine the seabed for petroleum and metals. Leaving land in its natural state is another, more subtle form of land use, since wilderness, parks, and preserves may still satisfy human demands for recreation and for ecosystem services such as water catchment, and the control of land erosion.

Medda et al. (2003) opined that "Urban land use is contingent upon the transportation system which is in turn dependent on business development in the city." Consequently, the rise in road traffic and the subsequent increase in land use devoted to road infrastructure have produced many externalities that directly and indirectly affect the morphology of cities (Ladd and Wheaton, 1991). Transportation is an integral of city land use. Hence, it has to be put into consideration when discussing land use issues because roads are the main arteries that make movement within and outside cities possible.

Every settlement consists of buildings and other structures; open and enclosed spaces and circulation channels. These elements are arranged in varying degrees and ways to create a form and structure peculiar to that setting (Achi, 2004). In other words, the field of Urban Design is viewed as holding the key to the creative activity. By this, the form and character of the physical environment may be devised, modified and controlled, in circumstances of social, economic, technological and/or political change, (Tibbalds, 1988). A city can display textures, which are a reflection of organization of activity patterns and their form,(Bacon, 1967). European cities vary from the composition of indigenous cities found in Nigeria (Breese, 1966).

The existence of cities attest to the fact that is in use and Akure the capital city of Ondo state is a typical example of this. The urban core as indicated in this paper is expressed by the area covered by Akure in 1966 which according to Ogunbodede (2006) is $3.66 \mathrm{~km}^{2}$. Oyinloye said in 1965 the population of Akure was 108 000. And this area is the oldest part of the city before further expansion occurred. Though Akure is still experiencing expansion, this paper focuses only on land use patterns within the area covered by the city in the year 1966 .

\section{Land Use Planning and Urban Design}

Land use planning provides guidance for the physical development of land - for making desirable places to live that serve people's needs. Those needs include homes, businesses, employment, recreation, and many others. Planning also includes the connections-transportation, public facilities, and utilities. Planning coordinates all of this development with the natural environment that surrounds and enhances our communities. Urban design connects and defines the details of the overall land use and transportation framework by guiding and defining the architectural and landscape characteristics of an area's streets, sites, and buildings. Urban designers work to create a consistent, functional, and harmonious community with a focus on creating a high-quality civic environment.

\section{Mixed-Use}

One of the most effective ways to create a liveable community is to place residential areas and employment, commercial, service, and recreational land uses as well as open space in close proximity. This creates those choices where to live, where to work, where to shop, and where to play in the park. It also 


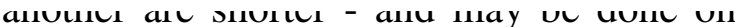
foot, on a bicycle, in a car, or by transit.

Liveable communities are vibrant places where there is activity on the streets all day and much of the all night. Busy communities are also safer because there are more people about more of the time more "eyes on the street" to deter antisocial behaviour.

\section{Density}

Higher density residential development is needed in order to create and enjoy the benefits provided by more compact places such as walk able neighbourhoods and centres, better transit service, and fewer automobile trips. More compact settlement patterns also allow for the opportunity to protect larger, contiguous tracts of natural areas and agricultural land from development. By promoting higher residential density within an amenity-rich, mixed-use urban context, a city moves much closer toward achieving its goal of creating liveable communities in its designated Development Areas.

\section{Land Use}

Land in Law, means a lot more than ground or soil, it includes 'land or any tenure, mines and minerals and other corporal hereditament; and easement, right, privilege, or benefit in, over or derived from land, (Hemuka, 2002). Land use on the other hand, refers to the use to which a particular land piece is put. Land can be put to different uses such as residential, commercial, industrial, administrative, agricultural or educational. Land use within a planned space should show a discernible and recognizable pattern. Fasina, (1996) defined Land Use as "kind of permanent or cyclic human intervention with the land to satisfy human needs. It is the application of human control on natural ecosystem in a
UCIIVC UCIICIIL IIUIIIL ( V IIIA, IフIJ).

The parameters to look into are as follows:

i. Land Use Patterns

ii. Land Utilization types

iii. Land Degradation/Land Evaluation

iv. Land Use/Land cover Classification

v. Land Use changes

vi. Land Use, Values and Ownership

vii. Land Use, and Physical Development

However, the scope of this paper does not include an in-depth study of these parameters.

Carter (1981) analysed the "range of studies", which is covered by the simple term "urban land use" in all its ramifications and concluded that it is possible to isolate three approaches:

i. Ecological Approach

ii. Economic Approach

iii. Activity Approach

The Ecological Approach uses the Growth Theories, the Economic Approach dwell on the Land Economics and Urban Land Use and the Activity Systems can be defined as "behaviour patterns of individuals institutions and firms which occur in spatial pattern", Carter, (1981).

\section{Land Use Types}

Land use type is the geographical division of land based on some combination of natural factors such as soil, relief, climate and vegetation interacting in interplay with other natural and socioeconomic factors. The term is often used to indicate man's use of the land; such as for agriculture, grazing, mining, forest, and urban development, (John, 1996; Adeyanju, 2005). The processes of urban land use development in the cities of Nigeria have led to the emergence of various types of land-use activities in the urban centres of the country. Among the dominant land use 
types in most urban centres in the country are: residential, commercial, industrial, public and semi-public, transport and communications, recreation and primary production, (Onokerhoraye and Omuta, 1998. P.158). Fasina,(1996) adopted a land use types classification system adopted below encompassing various land use types, after Anderson et al (1976).

\section{Land Use Changes}

\section{Morphology of Yoruba Towns}

Ojo (1966) did an analysis of the morphology of towns in Yoruba land. He stated that the growth of the cities took three forms:

a. A filling up of pre-colonial part of the settlement with development: i.e. the area within the walls or trenches/ramparts.

b. An expansion along the peripheries and a growth along the vertical axis of the city which was due to the first deliberate effort of the Europeans to stay clear of the indigenous areas and to build schools and other facilities far, where adequate land was available.

c. The third level of growth is sharply suggestive of change whence the traditional skyline of the typical Yoruba town has disappeared and replaced with juxtaposition of buildings of various forms and heights. The typical compound had disintegrated and singlefamily units have taken over.

d. Another level of growth apart from the three identified by Ojo (1966) is the construction of tenement houses.

e. The latest move is distortion of post modernism i.e. post-modern architecture.

\section{Land Use Pattern}

\section{Characteristics of Inhabitants of Cities}

The characteristics of the inhabitants of the urban centres of the developed countries, is grossly different from those of the developing ones: in fact an understanding of the pattern of the western urbanization is inadequate preparation to understand the developing world (Breeze, 1966). Some questions are raised as a result of urbanization in the developing regions.

\section{Statement of Research Problem}

Akure, the capital city of Ondo State in Nigeria has been experiencing expansion in terms of population and population density. The pattern of land use and developed in the city centre has been has consistently lacked control. The resultant effect is the overcrowding which is birthed by land abuse. This means that lands are not used for their real purposes, because residents try to maximize every inch of their land. Residents combine land use in ways that are not befitting of a city centre and this usually culminates in developments of slums. This study aims to identify the extent of this problem using Akure base map of 1966 to define the city centre which is the immediate surroundings of the Oba's palace, the main Oba's market, and the Akure central mosque.

\section{Research Questions}

The aim of this research is to answer the following questions;

i. What are the factors responsible for the pattern of land use in Akure city centre?

ii. What measures can be put in place to ensure proper land use in Akure city centre?

iii. Is lack of education directly responsible for improper land use in Akure city centre?

\section{Aim and Objectives}

The aim of the study is to identify the land use patterns in Akure City Centre. The objectives of this work are to: 
i. Define the city centre using the geographical survey map of Akure 1966.

ii. Identify the land use types within Akure city centre.

iii. Examine the correlation between level of education and land use pattern.

\section{Justification for the Study}

This study aims to solve the problem of improper land use in Akure city centre. It has been discovered that in Akure city centre, land abuse is a major problem. Some of the causes are: lack of education on the part of residents about the dangers inherent in indiscriminate use of land; insufficient conduct of research to make findings about the implications of inappropriate land use; negligence of the environment due to interest in monetary gains, etc. The findings of this research will greatly contribute to appropriate land use in Akure city centre; hence can lead to the development of a land-use model of what the city centre should look like.

\section{Scope of the Study}

The scope of this paper is limited to Akure city centre as defined by the base map of 1966. Though the city has expanded beyond this limit, the study will not exceed this limit. It will comprise of all types of buildings; residential, commercial, cultural, industrial, institutional, mixed use, etc, that are found within the area of study.

\section{The Study Area}

This study was carried out in the urban residential core of Akure metropolis. Akure, which is the capital of Ondo State, has a population of 360,268 (National
Population Commission, 2006). Using 2\% yearly increase, it is expected that by 2015 it would rise to 430,553 and 475,365 by the year 2020. It is located some $311 \mathrm{~km}$ North East of Lagos, about 370m above sea level and lies on longitude $5^{\circ} 18^{\prime}$ East and Latitude $7^{\circ} 17^{\prime}$ North of the Equator. The urban core, which happens to be the oldest residential portion of the city, consist of the oldest structures in the city and is bounded by Oba AdesidaRoad to the North, OkeAroRoad to the West and Hospital road to the East.

The rapidity of the city's development within the last twenty-five years arose from the political status of the town which was initially a provisional headquarter and later a state capital thus serving as the seat of both the local and State Governments since 1976. This accounted for the influx of people to the city for employment and other related activities. It is thus expected that the environmental situation would be critical in terms of the ability to meet up with the sporadic developments devoid of adequate planning and monitoring. In addition, the state has been classified as an oil-producing state while Akure has been classified as a Millennium Development City. All these factors are expected to greatly influence the population growth of the city.

The area under study is the urban core of Akure metropolis with the Oba's (king's) palace at the centre. Figure 7 shows the Geological survey map of Akure as it was in 1966 and the city centre for this paper is defined by this. The areas covered by Akure in 1966 include Isolo, Arakale, Hospital road, Ondo by-pass area, NEPA area, Isikan, and Araromi areas. 


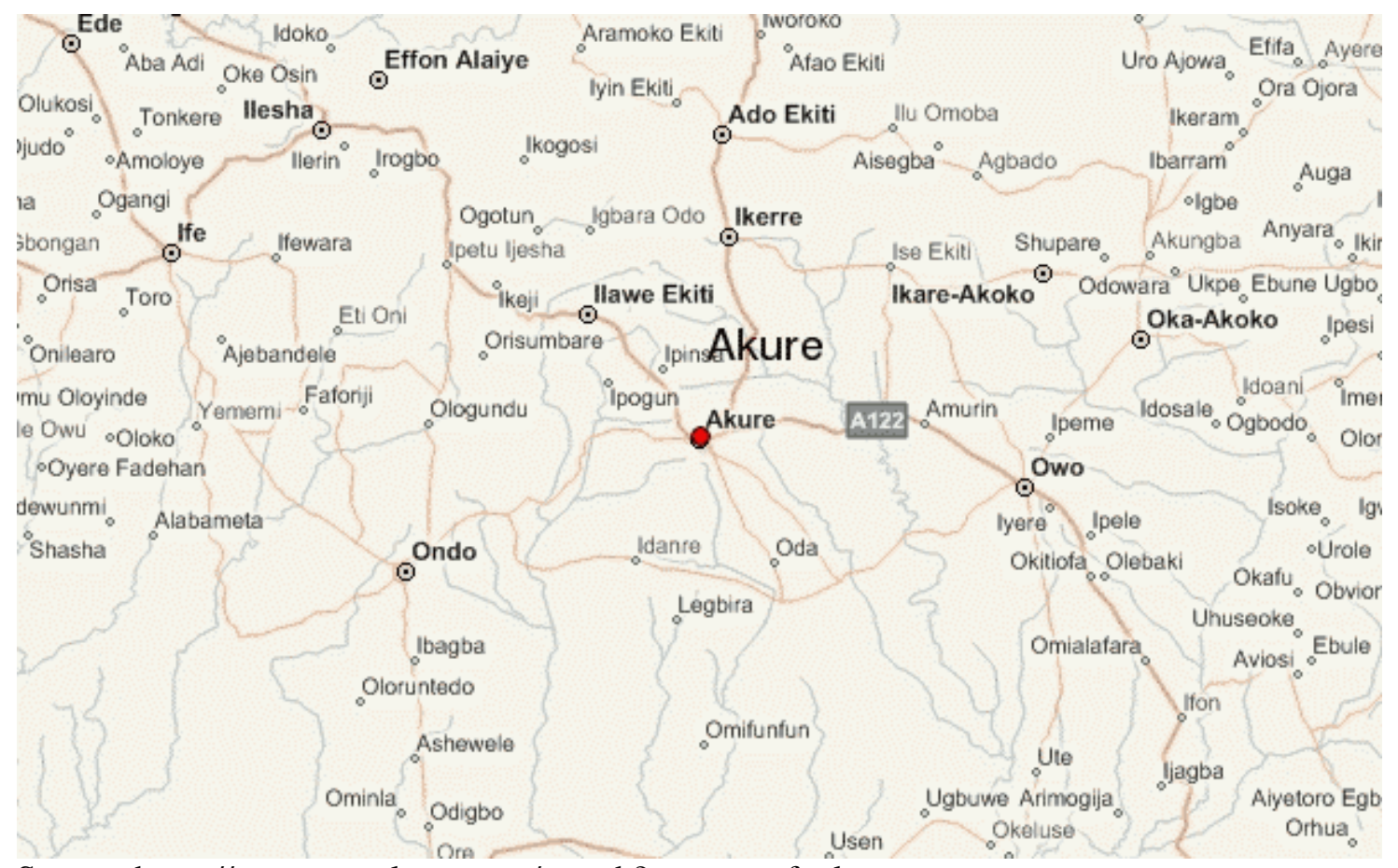

Source: https://www.google.com.ng/search?q=map+of+akure

Figure 1: Map of Akure

\section{Methodology}

\section{Experimental Design}

Data Collection

The research methodology includes:

\section{Primary data}

Structured questionnaires were used to collect relevant information from residents of the city centre about their various land uses. Field study was conducted and controlled observations were made about the land use patterns prevalent in the study area. Interviews were also conducted with the various land owners in the study area in order to gather relevant information for the study.

\section{Secondary data}

Internet search was carried out for information. Information and data were gathered from published materials in the form of textbooks, journals, etc. Other sources include; unpublished sources, seminar papers, review of relevant literature to know what similar works has been done in the past.
Information from the map of Akure 1966 which shows the delimitation of Akure city centre sourced from the Geographical Survey Agency of Nigeria. Information from the map of Akure 2005 sourced from the Ministry of Lands and Housing, Akure.

The Nigerian Ordinance Survey Map of Akure, Edition 1; Sheet 264: 1966 (which shows Akure City Centre) and the map of Akure 2005 (sourced from Ondo State Ministry of Lands and Housing, Akure Cartography Department) were the maps used. The 2005 Map was retraced and the 1966 map superimposed upon it to delineate the Akure city centre. After the centre was marked out, it was divided into strata for the purpose of distributing questionnaires in a stratified manner.

For the purpose of administration of questionnaires, this area was divided into strata as shown in figure 9 below. 


\section{Result and Discussion}

From table 1, it is observed that $50 \%$ of the respondents in zone A were not literate and $67 \%$ of the respondents in zone B had only Senior School Certificates. $100 \%$ of the respondents in zone $\mathrm{B}, \mathrm{C}$ and $\mathrm{D}$ earn less thanN30, 000 monthly, while $67 \%$ of the respondents in zone A earn above $\mathrm{N} 30$, 000 monthly. $70 \%$ of the respondents in zone $\mathrm{A}$ and $83 \%$ in zone B were selfemployed, while $58 \%$ in zone $\mathrm{C}$ were unemployed. $82 \%$ in zone $\mathrm{B}$ and $62 \%$ in zone $\mathrm{D}$ were into trading.

Table 1: Socio-economic background of Respondents

\begin{tabular}{|l|c|c|c|c|}
\hline & $\mathrm{Za}(\%)$ & $\mathrm{Zb}(\%)$ & $\mathrm{Zc}(\%)$ & $\mathrm{Zd}(\%)$ \\
\hline Educational background & & & & \\
Not literate & 50 & - & 28 & 38 \\
Adult literacy class & - & 8 & - & - \\
Primary school & 10 & 8 & 14 & 12 \\
SSCE & 10 & 67 & 14 & 38 \\
Post SSCE & 30 & 17 & 44 & 12 \\
\hline Income level per month & & & & \\
Low income & 33 & 40 & 60 & 100 \\
Average income & - & 60 & 40 & - \\
High income & 67 & - & - & - \\
\hline Employment Status & & & & \\
Government employed & 20 & - & 14 & 25 \\
Self-employed & 70 & 83 & 14 & 50 \\
Unemployed & - & 9 & 58 & 12 \\
Private company employed & 10 & 8 & 14 & 13 \\
\hline Occupation & & & & \\
Farming & 30 & - & 28 & - \\
Civil servant & 20 & - & 28 & 38 \\
Teaching & - & 9 & - & - \\
Trading & 30 & 82 & 28 & 62 \\
Artisan & 20 & - & 16 & - \\
Professional & - & 9 & - & - \\
\hline
\end{tabular}

From table 2, 60\% and $75 \%$ of the properties were rented or leased in zone A and B respectively, while $58 \%$ of those in zone $\mathrm{C}$ were occupied by their owners. $75 \%, 57 \%$ and $75 \%$ of the lands in zones $\mathrm{B}, \mathrm{C}$ and $\mathrm{D}$ respectively were acquired and the buildings constructed before the year $1970.100 \%$ of the properties under study in zones B, C and D are tenement buildings and therefore residential. 
Table 2: Building and Land Use

\begin{tabular}{|c|c|c|c|c|}
\hline & $\mathrm{Za}(\%)$ & $\mathrm{Zb}(\%)$ & $\mathrm{Zc}(\%)$ & $\mathrm{Zd}(\%)$ \\
\hline \multicolumn{5}{|l|}{ 1. Ownership Type } \\
\hline Owner Occupier & 40 & 25 & 58 & 50 \\
\hline Rented/ Leased & 60 & 75 & 42 & 50 \\
\hline \multicolumn{5}{|l|}{ 2. Mode of Land Acquisition, if owner occupier } \\
\hline Government purchased & - & - & - & - \\
\hline Purchased from individual & 20 & 35 & - & - \\
\hline Purchased from family & 60 & 40 & 84 & 50 \\
\hline Inherited & 20 & 25 & 16 & 50 \\
\hline \multicolumn{5}{|l|}{ 3. Year of land acquisition } \\
\hline Before 1970 & 30 & 75 & 57 & 75 \\
\hline $1971-1980$ & 20 & 25 & - & 25 \\
\hline $1981-1990$ & 10 & - & 43 & - \\
\hline $1991-2000$ & 30 & - & - & - \\
\hline $2001-2010$ & 10 & - & - & - \\
\hline \multicolumn{5}{|l|}{ 4. Year of erection of building } \\
\hline Before 1970 & 30 & 75 & 57 & 75 \\
\hline $1971-1980$ & 20 & 25 & - & 25 \\
\hline $1981-1990$ & 10 & - & 43 & - \\
\hline $1991-2000$ & 30 & - & - & - \\
\hline $2001-2010$ & 10 & - & - & - \\
\hline \multicolumn{5}{|l|}{ 5. Type of building } \\
\hline Tenement & 70 & 100 & 100 & 100 \\
\hline Flat & - & - & - & - \\
\hline Storey building & - & - & - & - \\
\hline Maisonette & - & - & - & - \\
\hline Shop & 30 & - & - & - \\
\hline \multicolumn{5}{|l|}{ 6. Size of building plot } \\
\hline $15 \mathrm{~m} \times 30 \mathrm{~m}$ & 10 & 16 & 57 & 12 \\
\hline $15 \mathrm{~m} \times 36 \mathrm{~m}$ & 30 & 32 & 43 & 13 \\
\hline $18 \mathrm{~m} \times 36 \mathrm{~m}$ & - & 32 & - & - \\
\hline $18 \mathrm{~m} \times 30 \mathrm{~m}$ & 60 & 10 & - & 62 \\
\hline $21 \mathrm{~m} \times 42 \mathrm{~m}$ & - & 10 & - & 13 \\
\hline \multicolumn{5}{|l|}{ 7. Activities performed on the land } \\
\hline Educational & - & - & - & - \\
\hline Industrial & - & - & - & - \\
\hline Commercial & 30 & - & - & - \\
\hline Agricultural & - & - & - & - \\
\hline Religious & - & - & - & - \\
\hline Cultural & - & - & - & - \\
\hline Government/ Administrative & - & - & - & - \\
\hline Residential & 70 & 100 & 100 & 100 \\
\hline Recreational & - & - & - & - \\
\hline Civic & - & - & - & - \\
\hline
\end{tabular}

majority of respondents are low income earners working in the informal sector most of which are Senior Secondary School Certificate holders or less. In fact, $50 \%$ of 
the respondents in zone A have no formal education. Most of the land owners in the city centre have little or no education. Hence, most do not realize the dangers of not adhering to stipulated setbacks from the roads since observations reveal that most of the buildings are too close to the roads. Some of the residents also extend their buildings in order to create shops in the residential environments without proper approval from the town planning authorities. Majority of the respondents were traders several of whom either trade in the market or in the shops they constructed in their houses or both.

Majority of the buildings were tenement buildings constructed before 1970, and were built with laterite and

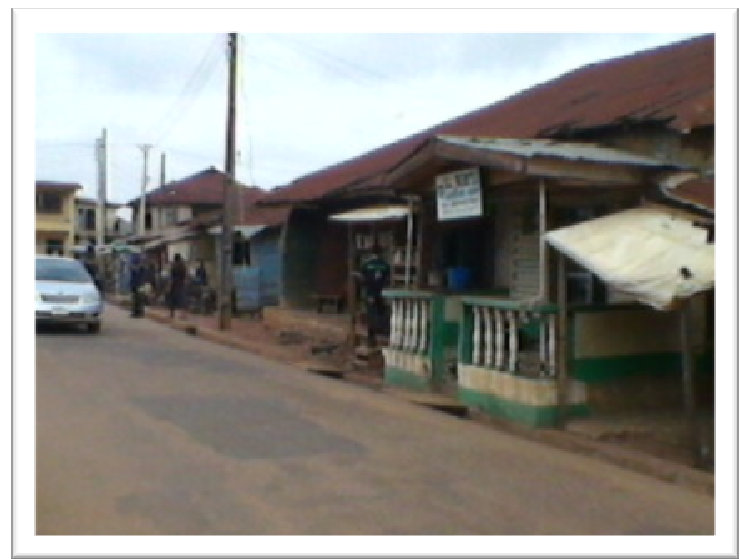

Figure2: showing blatant disregard for setbacks

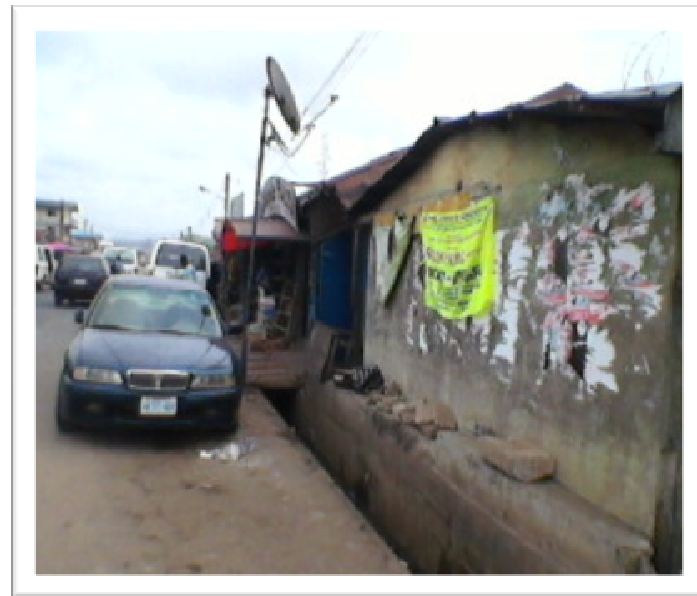

Figure 4: Building constructed virtually on the along Araromi road, Akure. finished with mortar to depict the technology used in construction of cheaper houses in those years. Also, interviews revealed that in those years there was no town planning authorities hence, the reason for lack of development control in the area and that since they were low income earners they try to maximize their land in any way they can to earn more financially. Obviously, such practices degrade the land. The most significant impact on the environment is the disorderliness it palpably displays. Several of the buildings are just too close to the roads and this reduces the right-of-way. Hence, if corrections were to be made will entail the demolition of all or a part of such buildings.

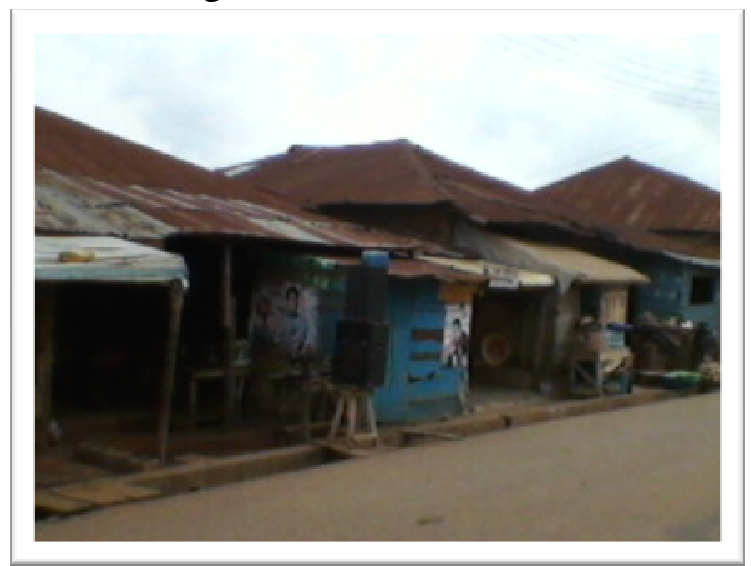

Figure 3: showing how residents extend their buildings close to the drainage channel to create illegal shops

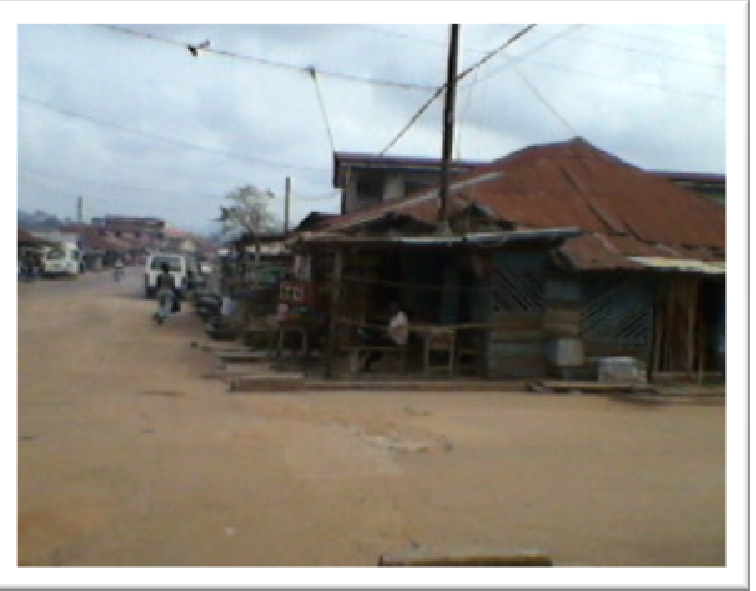

Figure 5: showing extension of a building to drainage create channel shops in front of residences illegally. 


\section{Conclusion}

This paper has revealed the need to sustain the quality of the urban environment by ensuring that land is put to appropriate use. This in turn has a direct bearing on urban aesthetics, public health and hygiene since it would discourage the growth of slums in the city centre. Sustainable urban development aims at reducing poverty to improve the quality of the urban environment and promote urban economic growth. The proper land use in Akure metropolis as elucidated in this paper, will give a sense of inclusion to the residents, who would have understood the need to adhere strictly to building regulations and put land to proper use. Hence, the entire urban population stands to benefit, as the urban core and its environs will become less congested, bringing the benefits of urbanization to the people and improving the beauty of the urban centre.

\section{Recommendations}

The recommendations for this study include among others that:

i. There should be appropriate sensitization of public about issues concerning land and its appropriate uses so that people can benefit from it.

ii. Community participation by way of meeting on relevant issues such as land use should be encouraged.

iii. There should be adequate provision of facilities in the city centres with the accompanied proper maintenance outfits.

iv. There is need to conduct periodic monitoring from time to time to discover the problems emanating from the current government proposals.

v. There should be development control in every part of the city especially the city centres because they are more vulnerable to slum development.

vi. Further work on the topic could lead to the development of a more realistic model of the city centre.

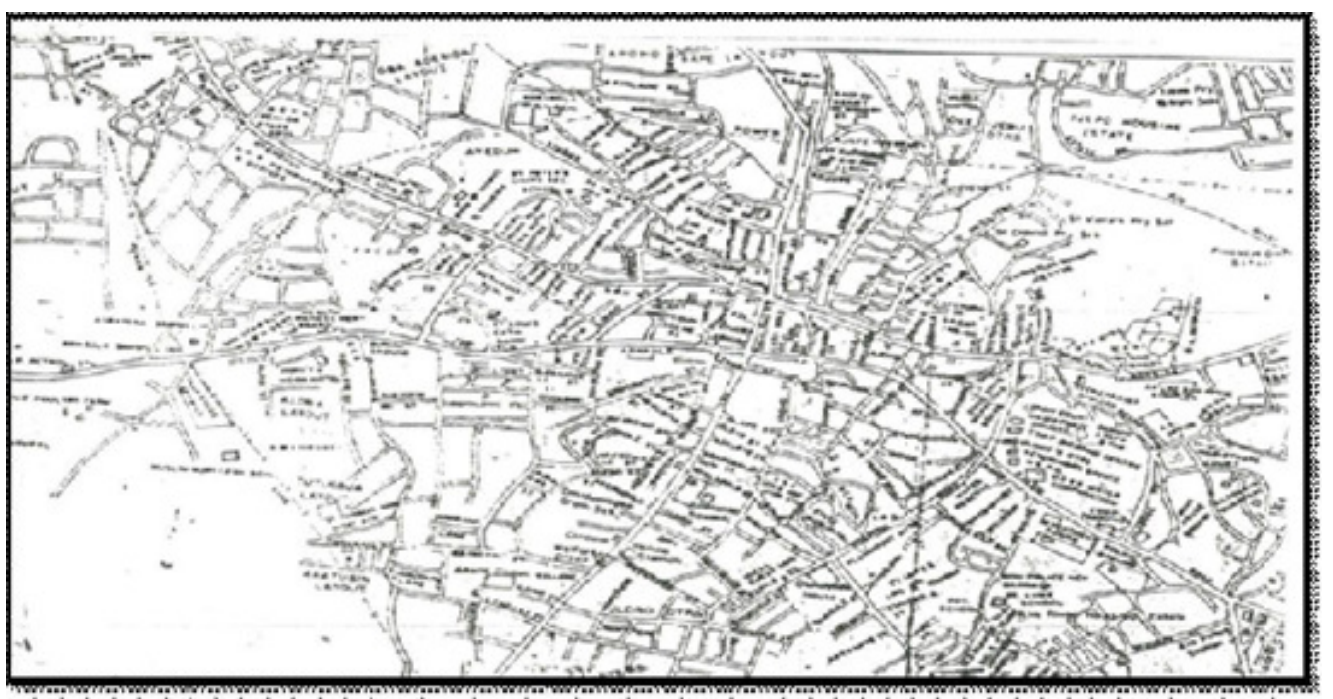

Figure 6: Map of Akure showing the road network 1996

Source: Ministry of Land and Housing Akure, Catography Department 


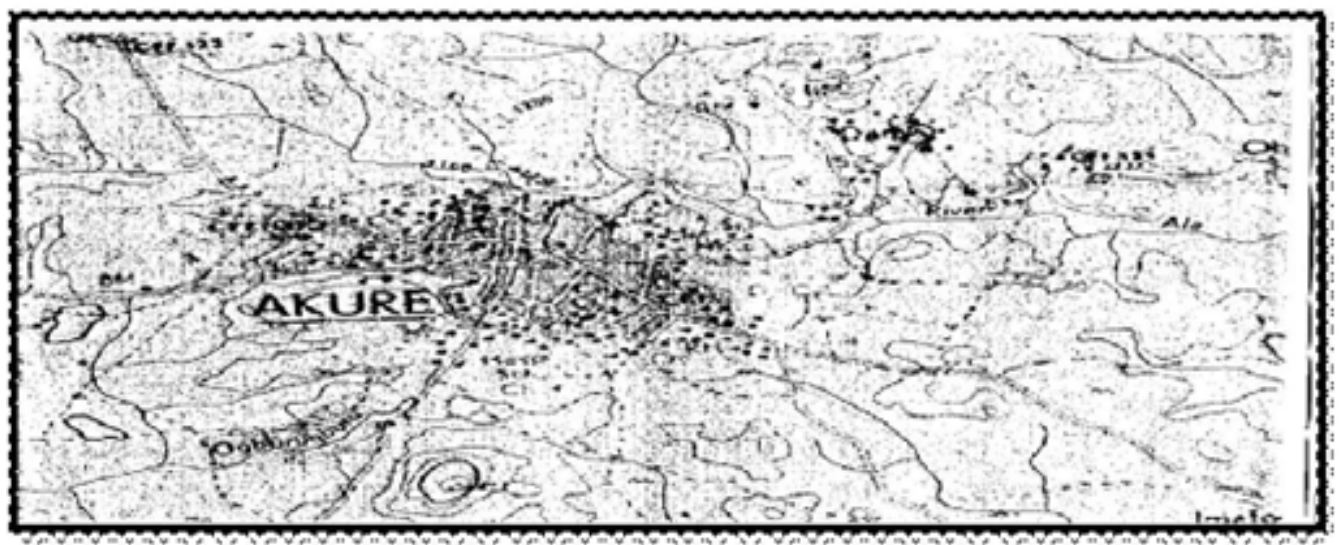

Figure 7: Geological survey map of Akure city centre 1966

Source: Ministry of Land and Housing Akure, Catography Department

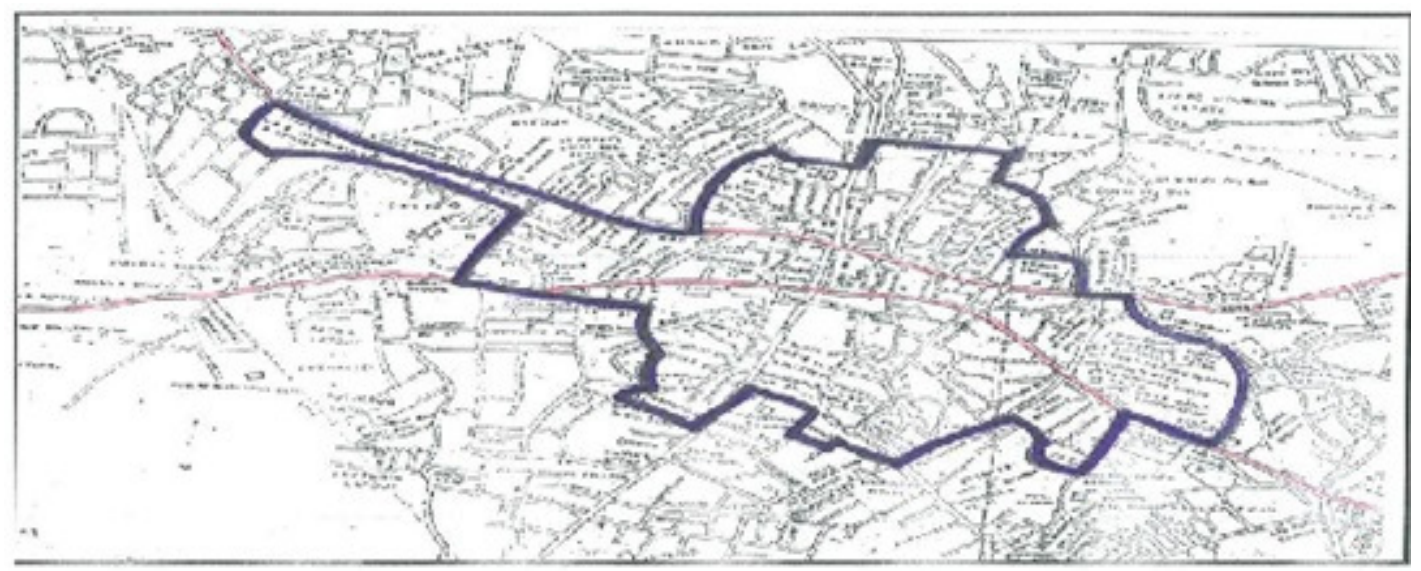

Figure 8: Map of Akure delineating the city centre

Source: Ministry of Land and Housing Akure, Catography Department

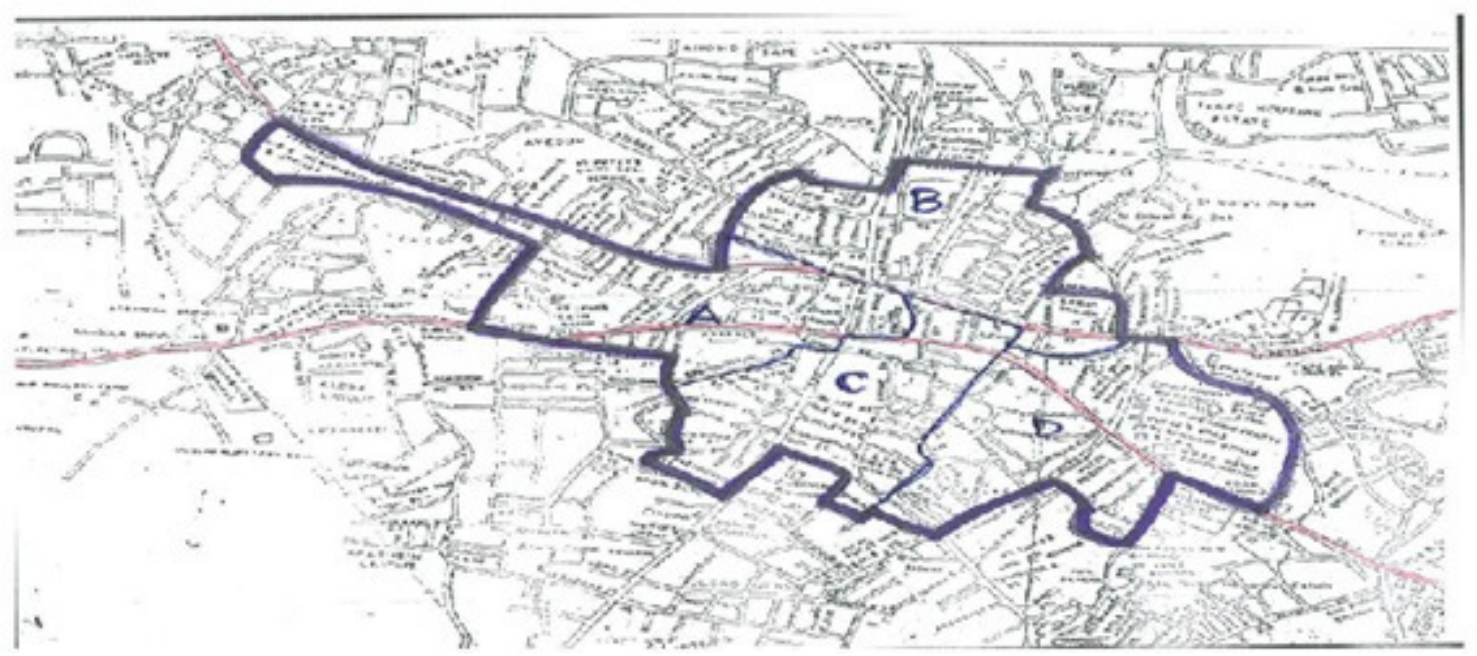

Figure 9: Map of Akure delineating the city centre and the stratified zoning for administration of questionaires

Source: Ministry of Land and Housing Akure, Catography Department 


\section{References}

Achi, L.B. (2004). Urban Design in Nigeria, Yambe Enterprises, Kaduna.

Adeyanju, A. (2005). Evaluation of the Potential of Some Soil around the University of Ado-Ekiti for Arable Crop Production, Unpublished Bachelor of Agricultural Thesis. Faculty of Agriculture, University of Ado-Ekiti, Nigeria.

Anderson, J.R., Hardy, E.E. and John, T. R. (1976). A Land Use and Land Cover Classification System for Use with Remote Sensing Data.US Geological Survey Professional Paper. 964-972

Bacon, E.N. (1967). Design of Cities, Viking Press, New York.

Breese, G. (1966). in Newly Developing Countries.Bureau of Urban Research, Princeton University, Prentice-Hall, Englewood Cliffs, New Jersey.

Carter, H. (1981). The Study of Urban Geography. Third Edition, Edward, Arnold, London.

Ciborowski, A. (1970). Planning and Urban Renewal. http://www.jstor.org/pss/1475536

Encarta (2008). World English Dictionary.Bloomsbury Publishing Plc. Redmond. United States of America.

Fasina, A.S. (1996). Land Use and Quality in selected Areas of Lagos State. Unpublished $\mathrm{PhD}$ Thesis, University of Ibadan, Oyo State.

Hemuka, N. (2002). The Test of Professional Competence, A Handbook for the Estate Surveyora and Valuer, Hemuka Real Estate Publishers, Benin, First Edition, Page 530.

Jameson, M. (1991). Private space and the Greek city. In O. Murray and S. Price (eds), The Greek City: From Homer to Alexander. Oxford: Clarendon Press.

John, N.W. (1996). A Dictionary of Agricultural and Allied Technology.

Ladd, H.F. and Wheaton, W. (1991). Causes and Consequences of the Changing Urban Form: Introduction. Journal of Regional Science and Urban Economics, 21(2): 157-162.

Medda, F., Nijkamp, P. and Rietveld, P. (2003). Urban Land Use for Transport Systems and City Shapes. Geographical Analysis. 35(1): 46-57.

Mitchel, C.N. (1962). Yoruba Towns, in K. M. Barbour and R. M. Prothero eds. Essays in African Population (New York: Fredrick, A Praeger, Inc. 279301

Mitchell, C.W. (1956). Terrain Evaluation, Longman, London.

Ogunbodede, (2006). Assessment of Traffic Congestions in Akure (Nigeria) using GIS Approach: Lessons and Challenges for Urban Sustenance. Research funded by Adekunle Ajasin University, Akungba Akoko, Ondo, Nigeria

Ojo, G.J.A. (1966). Yoruba Culture: A Geographical Analysis.University of London Press, London Pg 131

O’Neill, J. (2000). Galway: Inner City Urban Renewal and Land Use diversity. Urban renewal and Planning

Onokerhoraye, A.G. and Omuta, G.E.D. (1998). Urban System and Planning. Published by Editorial Committee, Geography and Planning Series. University of Benin. 158.

Oriye, O. (2008). The Impact of Urban Expansion on the Land Use Types of Ado-Ekiti. Unpublished Ph.D thesis, Department of Geography and Planning Sciences, University of Ado-Ekiti, Ekiti State. 
Oyinloye, M.A. (2013). Geospatial Analysis of Urban Growth- The Case of Akure, Nigeria. African Journal of Social Issues and Humanities, Vol 3/Issue 4/July 2013/ 200.

Pocket Oxford Dictionary (1994). Oxford University Press, Walton Street Oxford, England.

Tibbalds, F. (1988). Mind the Gap! A personal view of the value of the $20^{\text {th }}$ Century, in the Planner Volume 74 No 3, Journal of the Royal Town Planning Institute, London.
Vink, A.P.A. (1963). Planning of Soil Survey in Land Development. Veemanen Zones, Wageningen.www.ci.minneapolis.mn. us/cped/landuse-urbandesign.pdf

http://www.fig.net/pub/fig2010/papers/ts06 e\%5Cts06e_schetke_haase_et_al_462 6.pdf

www.albemarle.org/.../PL29Info5LandUse UrbanDesign2-20-07Final.pdf

http://www.fao.org/nr/land/use/en/, Food and Agricultural Organisation of the United Nations, accessed 13-02-2015 